\title{
Bioactivities of Phenolics by Focusing on Suppression of Chronic Diseases: A Review
}

\author{
Fereidoon Shahidi * (1) and JuDong Yeo \\ Department of Biochemistry, Memorial University of Newfoundland, St. John's, NL A1B 3X9, Canada; \\ jy2402@mun.ca \\ * Correspondence: fshahidi@mun.ca; Tel.: +1-709-864-8552
}

Received: 4 May 2018; Accepted: 23 May 2018; Published: 25 May 2018

\begin{abstract}
Phenolics, which are secondary metabolites of plants, exhibit remarkable bioactivities. In this contribution, we have focused on their protective effect against chronic diseases rather than their antioxidant activities, which have been widely discussed in the literature. A large body of epidemiological studies has proven the bioactivities of phenolics in both standard compounds and natural extracts: namely, anticancer, anti-inflammatory, and antibacterial activities as well as reducing diabetes, cardiovascular disease, and neurodegenerative disease. Phenolics also display anti-analgesic, anti-allergic, and anti-Alzheimer's properties. Thus, this review provides crucial information for better understanding the bioactivities of phenolics in foods and fills a gap in the existing collective and overall knowledge in the field.
\end{abstract}

Keywords: phenolics; bioactivity; phenolic acid; flavonoids; anticancer; anti-inflammatory activity; antibacterial activity

\section{Introduction}

\subsection{Phenolics}

Phenolic compounds are secondary metabolites of plants. So far, more than 8000 phenolics have been found from natural sources and are classified into phenolic acids, flavonoids, stilbenes, coumarins, lignins, and tannins. Phenolics play a crucial role in plants by controlling their growth as an internal physiological regulator [1]. For instance, kaempferol, apigenin, and quercetin interact with plasma membrane proteins (receptors), in which they restrict the transfer of polar auxin compounds via the membrane, thus affecting plant growth [1]. Phenolics in the outer part of plants shield them from fatal high-energy wavelengths by absorbing them in advance; in other words, electron-rich parts such as the $\pi$-bond of the phenolics absorb the wavelength before attacking the critical parts of the cells.

\subsection{Classification of Phenolics}

Phenolic and polyphenolic compounds can be classified into several classes, namely phenolic acids, flavonoids, stilbenes, coumarins, lignins, and tannins. Phenolic acids constitute a primary phenolic class of compounds in natural sources such as cereals, legumes, and other seeds, in which they act as the building material of cell wall matrices by forming bridges with macromolecules such as cellulose, hemicellulose, and pectin, thus supporting the construction of compact cell wall structures. Thus, they generally occur in various conjugated forms other than the free type. Phenolic acids are divided into two groups, hydroxycinnamic acids and hydroxybenzoic acids. Hydroxycinnamic acids include $p$-coumaric, caffeic, ferulic and sinapic acids, while hydroxybenzoic acids encompass $p$-hydroxybenzoic, protocatechuic, vanillic, syringic and gallic acids (Figure 1). The differentiation is in the substitution and functional groups, namely hydroxyl and methoxy groups, 
which decide the individual differences of each phenolic acid. The ingested phenolic acids are absorbed in the gastrointestinal tract and then circulate in the blood system after methylation, sulfation, and glucuronidation in the liver [2]. For example, hydroxycinnamic acids in wines are absorbed in the gastrointestinal tract after ingestion and transformed into glucuronide and sulfate conjugates, followed by circulation in the blood [3]. This conjugation process increases the hydrophilicity of the phenolic compounds and helps remove them via the biliary or the urinary route.<smiles>O=C(O)c1cc(O)c(O)c(O)c1</smiles>

Gallic acid

(Hydroxybenzoic acid)<smiles>COc1cc(C(=O)O)cc(OC)c1O</smiles>

Syringic acid

(Hydroxybenzoic acid)<smiles>O=C(O)c1ccc(O)cc1</smiles>

p-Hydroxybenzoic acid

(Hydroxybenzoic acid)<smiles>O=C(O)/C=C/c1ccc(O)cc1</smiles>

$p$-Coumaric acid

(Hydroxycinnamic acid)<smiles>COc1cc(/C=C/C(=O)O)ccc1O</smiles>

Ferulic acid

(Hydroxycinnamic acid)<smiles>CCCCCCCCCCCCC=Cc1cc(OC)c(O)c(OC)c1</smiles>

Figure 1. Chemical structures of representative phenolic acids.

Flavonoids, another class of phenolics that have a three-ring structure in the C6-C3-C6 form, constitute different sub-classes of compounds such as flavones, flavonols, flavanones, flavanonols, flavanols, isoflavones, and anthocyanidins. These compounds may have different substitution patterns with hydroxyl and methoxy groups. Flavonoids possess remarkable bioactivities such as anticancer, anti-inflammation and anti-virus effects as well as reducing cardiovascular diseases and type-2 diabetes, which will be mainly discussed in this contribution.

Stilbenes, also known as 1,2-diphenylethene, possess a C6-C2-C6 carbon skeleton and show potent bioactivities such as antibacterial effects, among others. For example, tetrastilbenes such as kobophenol-A and -B display antibacterial activity against Staphylococcus aureus [4]. Stilbenes are also 
known as an active inhibitor of topoisomerase II, which causes unwinding of coiled DNA during cellular transcription [5]. Resveratrol, which is abundant in grapes and wines, is a representative example of stilbenes and has shown many bioactivities such as anti-inflammation, anti-tumorigenesis, and cardioprotective effects [6]. In addition, resveratrol is useful in the inhibition of Parkinson's and Alzheimer's diseases by moderating hemeoxygenase activity because the incorrect functioning of hemeoxygenase causes such ailments $[7,8]$.

Coumarins are referred to as benzopyrones with a C6-C3 skeleton and an oxygen heterocycle in the C3 unit, as shown in Figure 2 [9]. They are found in a wide variety of plants such as tonka bean (Dipteryx odorata), sweet woodruff (Galium odoratum), sweet grass (Hierochloe odorata), deertongue (Dichanthelium clandestinum), vanilla grass (Anthoxanthum odoratum), mullein (Verbascum spp.), and sweet-clover (Melilotus sp.). Aside from plants, coumarins are present as the metabolites of microorganisms such as Streptomyces and Aspergillus species, namely novobiocin and coumermycin [9,10].

Coumarins show a variety of bioactivities such as anti-inflammatory, antimicrobial, antiviral, antioxidant, antitumor, antiasthmatic, antidepressant, anti-HIV, and anti-Alzheimer's [11-14]. In addition, coumarin possesses anti-coagulant activity, which inhibits blood coagulation by suppressing the hepatic biosynthesis of vitamin K-dependent coagulation factors. Thus, coumarin is also used as an anticoagulant for the treatment of diseases such as thrombotic phlebitis and pulmonary embolism.

Moreover, phenolic compounds may occur in the polymeric type in plants; lignins are the polymers of monolignols such as $p$-coumaric acid and sinapic acid. Tannins are divided into two groups: hydrolyzable tannins such as ellagitannins and gallotannins; and condensed tannins, also referred to as proanthocyanidins. The latter group is further divided into several sub-classes depending on the type of linkage between the flavonoids, namely single or double linkages. Proanthocyanidins are widely distributed in plant-based foods such as lentils, grape seed, cocoa seeds, and apples, among others [15-17]. The structural properties of proanthocyanidins, especially those with two or three hydroxyl groups in the B-ring of flavan-3-ol unit, confer bioactivity; for instance, proanthocyanidin shows not only inhibitory activity against the oxidation of low density lipoprotein (LDL) cholesterol, stomach mucosa injury, and radioprotective effects against chromosomal damage, but also a practical bacterial anti-adhesion effect $[18,19]$. In addition, they possess a robust antioxidant potential such as oxygen radical scavenging capacity [20].

\subsection{Biosynthesis of Phenolics}

The biosynthesis of phenolics takes place at the surface of the endoplasmic reticulum (ER) in plant cells [21]. Phenylalanine and tyrosine are precursors for the biosynthesis of different classes of phenolics such as phenolic acids, flavonoids, stilbenes, coumarins, lignins, and tannins. A variety of enzymes including erythrose-4-phosphate, phenylalanine ammonia lyase (PAL), cinnamate-4-hydrolxylase, $p$-coumarate-3-hydroxylase, and o-methyl transferase are involved in the biosynthesis of phenolics [22]. Phenylalanine, which is synthesized via the shikimate pathway, and to a lesser extent tyrosine, are the primary precursors for the biosynthesis of different classes of phenolics. The enzymatic biosynthesis of phenolics begins with releasing an ammonia group of phenylalanine by phenylalanine ammonia lyase (PAL), and this step yields trans-cinnamic acid with the creation of a double bond (Figure 2). The produced trans-cinnamic acid is modified into $p$-coumaric acid by cinnamate-4-hydrolxylase, and subsequently, the assistance of $p$-coumarate-3-hydroxylase generates caffeic acid from $p$-coumaric acid after introducing a hydroxyl group to the aromatic ring. This $p$-coumaric acid is altered into ferulic acid by the action of $o$-methyl transferase, and so ferulic acid is converted into sinapic acid; two enzymes, hydroxylase and $o$-methyl transferase, are involved in the substitution of a methoxy group for the biosynthesis of sinapic acid. Tyrosine, another precursor, is also transformed into $p$-coumaric acid by detaching an ammonia group through the enzymatic reaction of tyrosine ammonia lyase and then $p$-coumaric acid is changed into different types of phenolic acids through the same reactions. In addition, benzoic acid is formed by losing two carbon atoms from phenylpropanoids. 


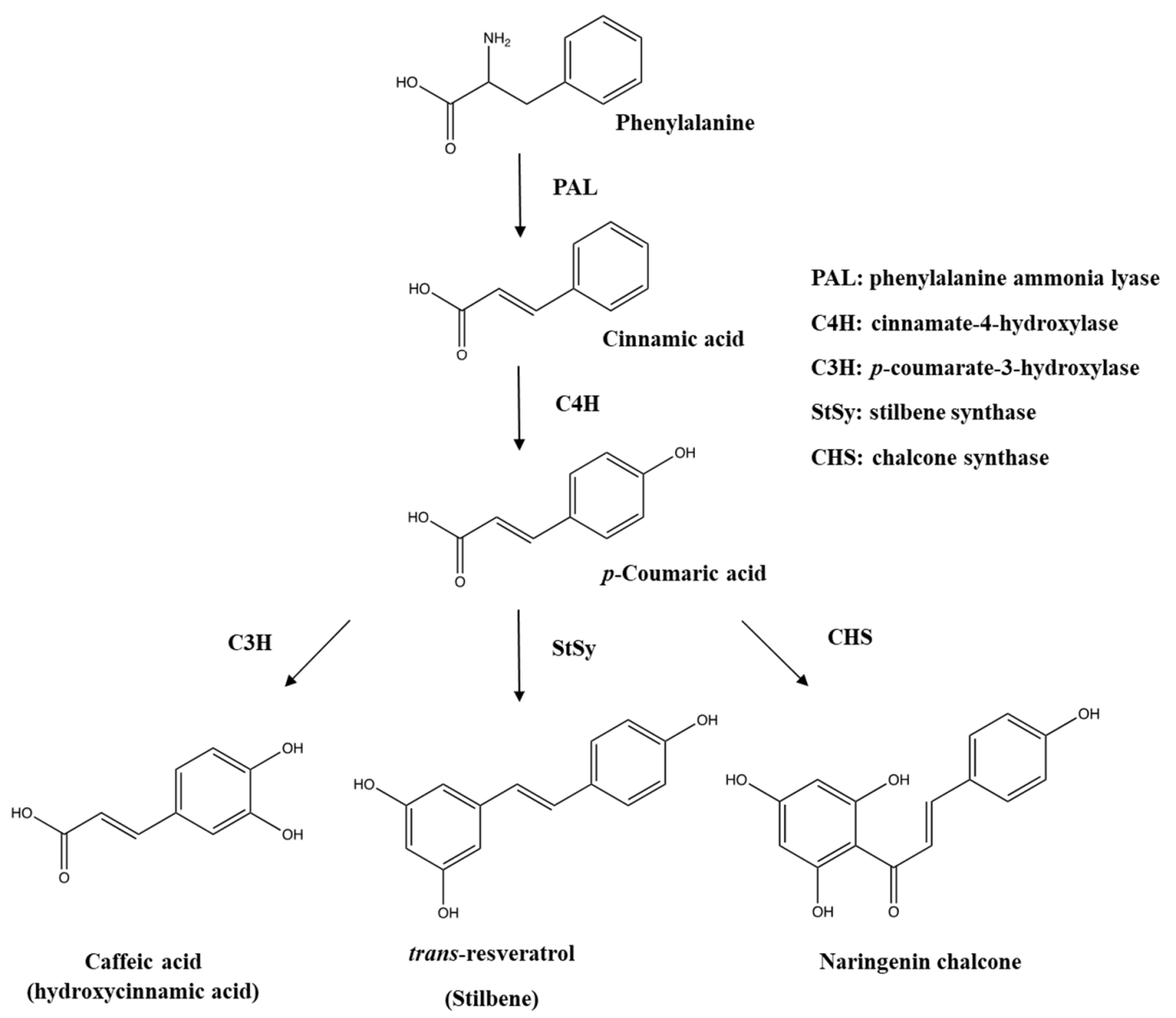

Figure 2. Biosynthesis pathway of phenolic acids and stilbene from phenylalanine.

Flavonoids' biosynthesis, referred to as the flavonoid branch pathway, starts with a combination of three molecules of malonyl coenzyme A ( $\mathrm{CoA}$ ) and $p$-coumaroyl CoA, leading to the formation of naringenin chalcone with the aid of chalcone synthase (CHS), followed by alteration into flavonone by chalcone isomerase. The produced flavonone is converted into different classes of individual flavonoids such as flavone, flavonol, flavononol, flavanone, isoflavone, and anthocyanins under suitable enzymatic reactions. For instance, flavonone is transformed into kaempferol and apigenin by flavonol synthase/flavanone-3-hydroxylase and flavone synthase as well as the production of genistein by isoflavone synthase.

\subsection{Transfer of Phenolics}

The phenolics synthesized in the ER transfer to other organs via membrane transporter proteins and vesicles. The phenolics secreted from the ER after biosynthesis move to the target organs and enter them through ABC (adenosine tri-phosphate (ATP) binding cassette) and MATE (multidrug and toxic compound extrusion) transporter proteins at the surface of the membrane. Phenolics also transfer to other organs through the vesicles. Vesicles, which are small sacs enclosed by a lipid bilayer, can contain liquids and essential molecules, and transport these compounds from one site to another throughout the cells. In the same way, the vesicles incorporate phenolics and transport them to target organs. A large proportion of the phenolics synthesized are transferred to the vacuole, in which they co-exist with other organic acids; approximately $80 \%$ of phenolics are localized in the vacuole. Meanwhile, some phenolics transfer to the cell wall matrix and form covalent bonds such as ester, ether, and $\mathrm{C}-\mathrm{C}$ bonds with cell wall substances (e.g., cellulose, pectin, arabinoxylan, and structural proteins). These phenolics are referred to as insoluble-bound phenolics since they are not isolated by the commonly used extraction media due to the covalent bonds to the insoluble macromolecules. 


\subsection{Absorption of Phenolics in the Digestive Tract}

Phenolics from plant-based foods undergo multi-enzyme reactions in the digestive tracts such as the mouth, stomach, small and large intestines (colon) after consumption. Phenolics in food matrix are biologically extracted in the gastrointestinal tract by different enzymes and $\mathrm{pH}$ conditions [23]. The phenolics liberated from the food matrix are absorbed in the small intestine. Once they pass through the epithelial cells, they simultaneously conjugate with other molecules such as glucuronic acid and sulfonate, followed by introduction in the plasma [24]. However, the small intestine absorbs only a small portion of free phenolics in the food matrices and only $5-10 \%$ of them are incorporated into the plasma; the remaining $90-95 \%$ are directly transferred to the colon [21]. The phenolics reaching the large intestine undergo fermentation by the versatile colon microbiota [25,26]. In the colon, approximately 1000 different microorganisms such as bacteria, fungi, protozoa, and archaea co-exist and take part in the elaborate fermentation process of unabsorbed material, including phenolics [27]. These microorganisms secrete extracellular enzymes, thus affecting the chemical structure of phenolics. The phenolics existing in the colon have a positive effect on health by reducing the $\mathrm{pH}$ of the colon, which inhibits the growth and proliferation of cancer-inducing microorganisms; for instance, phenolics from blueberries suppress the growth of colon cancer cell lines such as HT-29 and Caco- 2 by approximately $50 \%$ [28].

Epidemiological evidence has so far shown many health-promoting actions of the absorbed phenolics such as anticancer, anti-inflammatory, and anti-diabetes. This review discusses a variety of bioactivities of standard phenolics and phenolic extracts from natural origins such as grains, cereals, legumes, seeds, and fruits by focusing on their preventive effects against chronic ailments and summarizing clinical evidence.

\section{Bioactivities of Standard Phenolics}

\subsection{Anticancer}

Epidemiological evidence has demonstrated the remarkable health-promoting effects of phenolics on chronical ailments, including anti-carcinogenic, anti-inflammatory, and antioxidant activities (Table 1). The anti-carcinogenic capacity is a primary disease-preventive effect of phenolics; they retard the initiation and progression of cancers by constraining the transformation of normal cells, the growing tumors, angiogenesis, and metastasis. Moreover, phenolics stimulate the expression of tumor-suppressing proteins such as p53, phosphatase and tensin homolog (PTEN), p21, and p27 [29]. Gallic acid has shown significant anticancer activity in many studies by attenuating the growth of different types of cancer cells such as human leukemia (HL)-60 and DU-145 human prostate carcinoma cells $[30,31]$. Methyl gallate also suppresses the proliferation of human epidermoid carcinoma (A431) skin cancer cells [32]. The anticarcinogenic potential of other phenolic acids such as ferulic, feruloyl-L-arabinose and coumaric has also been investigated in several cell lines. Fahrioğlu et al. [33] reported that ferulic acid shows an anticancer effect by influencing the cell cycle, invasion, and apoptotic behavior of MIA PaCa-2 (human pancreatic cells). Eitsuka et al. [34] studied the synergistic anticancer potential of ferulic acid and $\delta$-tocotrienol against the proliferation of different cancer cells in which they found that this combination displays a better inhibitory effect on the proliferation of DU-145 (prostate cancer), michigan cancer foundation-7 (MCF-7, breast cancer), and PANC-1 (pancreatic cancer) cells compared to their individual use. Choi and Park [35] found that ferulic acid inhibits homologous recombination (HR) repair of DNA and RAD 51 (eukaryotic gene) formation in breast cancer cells. Moreover, ferulic acid revealed a remarkable chemotherapeutic effect in combination with veliparib treatment. Janicke et al. [36] noticed the protective effect of $p$-coumaric acid against the development of colon cancer by retarding the cell cycle progression of Caco-2 colon cancer cells. Feruloyl-L-arabinose suppressed penetration, migration, and production of reactive oxygen species (ROS) in lung cancer cells [37]. Furthermore, flavonoids such as troxerutin, apigenin, kaempferol, and myricetin have proven their excellent anticarcinogenic capacity. Panat et al. [38] 
studied the binding affinity of troxerutin to the DNA groove in order to induce cytotoxicity of prostate cancer cell using $\gamma$-radiation, and the result revealed an effective inhibition of the proliferation of that cancer cell. Apigenin displayed a radiosensitizing effect in human tumor cells in which the cancer cell treated with apigenin showed a higher radiosensitivity and apoptosis levels than that without apigenin [39]. Leung et al. [40] explored the apoptosis-inducing potential of kaempferol in human lung carcinoma cells, and they argued that the apoptosis of aforementioned cancer cell by kaempferol may be due to the alteration in apoptotic markers including caspase-3 (caspase-dependent) and apoptosis-inducing factor (AIF, caspase-independent). In addition, myricetin showed a strong anticancer capacity in 1,2-dimethylhydrazine-induced carcinogenesis in colorectal cancer of rat [41].

Table 1. Bioactivities of phenolic acids and flavonoids.

\begin{tabular}{|c|c|c|}
\hline & Bioactivity & Reference \\
\hline \multicolumn{3}{|l|}{ Phenolic Acid } \\
\hline \multirow{3}{*}{ Gallic acid } & Anticancer & {$[30,31]$} \\
\hline & HCV inhibition & [42] \\
\hline & Antibacterial & {$[43,44]$} \\
\hline Methyl gallate & Anticancer & {$[32]$} \\
\hline$p$-Coumaric acid & Anticancer & [36] \\
\hline \multirow{4}{*}{ Ferulic acid } & Anticancer & {$[33,45]$} \\
\hline & Alleviates angina pectoris & [46] \\
\hline & Reducing hypertension & [46] \\
\hline & Reducing type 2-diabetes & [45] \\
\hline Chlorogenic and Caffeic acids & Anti-mutagenic and-carcinogenic activity & [47] \\
\hline \multicolumn{3}{|l|}{ Flavonoid } \\
\hline Catechin & Preventing Parkinson's and Alzheimer's diseases & {$[48,49]$} \\
\hline (+)-Epigallocatechin 3-O-gallate & Anti-virus & {$[50]$} \\
\hline Quercetin & Anticancer & {$[51]$} \\
\hline \multirow{3}{*}{ Kaempferol } & Anticancer & {$[40,52,53]$} \\
\hline & Anti-inflammation & [54] \\
\hline & Osteoporotic activity & {$[53]$} \\
\hline Myricetin & Anticancer & [41] \\
\hline \multirow{2}{*}{ Apigenin } & Anticancer & [39] \\
\hline & Anti-inflammation & [55] \\
\hline Troxerutin & Anticancer & [38] \\
\hline Naringin & Anti-inflammation & [56] \\
\hline Hesperidin & Anti-inflammation & [57] \\
\hline Rutin & Anti-inflammation & [57] \\
\hline
\end{tabular}

\subsection{Anti-Inflammatory Activity}

Inflammation is an essential biological response to tissue damage. The immune system responds to stimuli such as infection, injury, or irritation through the release of pro-inflammatory cytokines [58]. The overproduction of pro-inflammatory cytokines such as interleukin (IL)-1b, IL-6, and tumor necrosis factor alpha (TNF- $\alpha$ ) cause severe adult ailments such as arthritis, allergy, atherosclerosis, and cancer (Figure 3) [52]. Thus, inhibition of overproduction of pro-inflammatory cytokines is vital in order to prevent related ailments. Phytochemicals from plant-derived formulations have been extensively used to treat inflammation and related disorders from the ancient time. Phenolics are essential compounds for the suppression of inflammation among phytochemicals, and the recent literature has revealed their potent anti-inflammatory capacity. Pragasam et al. [59] studied the anti-inflammatory effects of $p$-coumaric acid by monitoring the expression of tumor necrosis factor (TNF- $\alpha$ ) in synovial 
tissue of adjuvant-induced arthritic rats, and the potent anti-inflammatory activity of $p$-coumaric acid was found by lowering the expression of inflammatory mediator TNF- $\alpha$. Anti-inflammatory activity of caffeic acid and ellagic acid was also found by Chao et al. [60]; caffeic and ellagic acids were supplied to mice by mixing to their diet at a ratio of 2.5 and $5.0 \%$, and the treatment of those phenolic acids decreased the expression of inflammatory mediators such as IL-6, IL-1- $\beta$, tumor necrosis factor (TNF)- $\alpha$. da Cunha et al. [61] explored the anti-inflammatory capacities of caffeic acid and its derivatives, and their potent inhibition of lipopolysaccharide (LPS)-induced inducible nitric oxide synthase (iNOS) expression in RAW 264.7 macrophage was found. Chtourou et al. [56] evaluated the anti-inflammation capacity of naringin in cisplatin-induced nephrotoxicity in rats and found its effective anti-inflammation capacity. Kamel et al. [57] explored the efficiency of hesperidin and rutin on the attenuation of cisplatin-induced nephrotoxicity in rats; the administration of hesperidin ( $200 \mathrm{mg}$ /day) or rutin ( $30 \mathrm{mg} /$ day) for 14 days actively suppressed the inflammation of rats tested. Furthermore, apigenin ameliorated inflammation through the reduction of p53 activation in human renal proximal tubular epithelial cells [55]. In addition, kaempferol modulated pro-inflammatory enzyme activities, gene expression related to inflammation, and inhibition of transcription factor such as NF- $\mathrm{kB}$, showing unusual anti-inflammation activity [52]. Calderon-Montano et al. [54] also reported anti-inflammation potential of kaempferol. Hamalainen et al. [62] investigated anti-inflammation activities of representative flavonoids such as naringenin, quercetin, kaempferol, isorhamnetin, daidzein, and genistein as well as pelargonidin (anthocyanidin). All compounds listed above suppressed iNOS protein by inhibiting nuclear factor- $\mathrm{kB}(\mathrm{NF}-\mathrm{kB})$, which is a main transcription factor for iNOS.

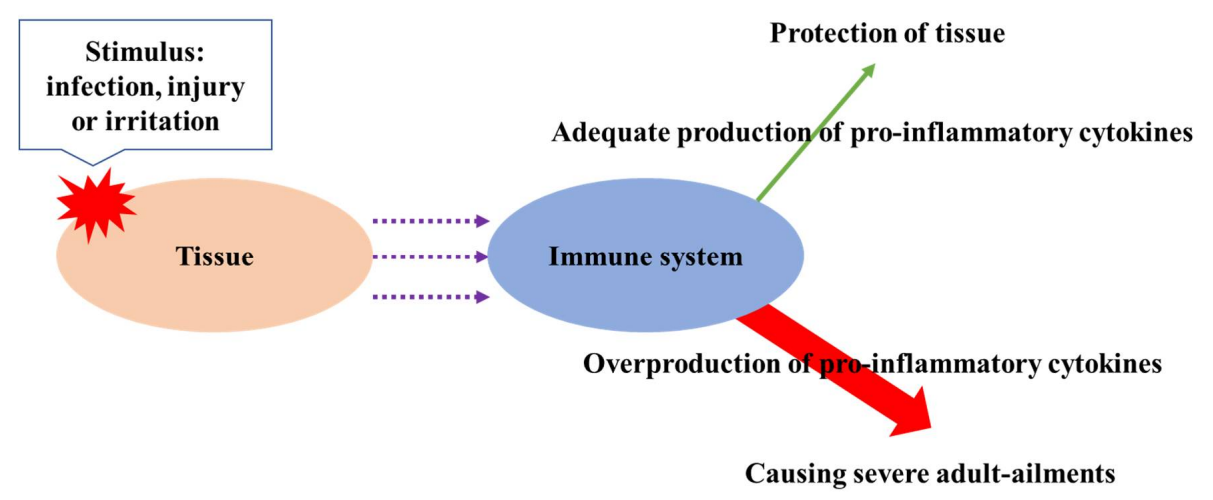

Figure 3. The occurrence of chronical diseases by the overproduction of pro-inflammatory cytokines.

\subsection{Antibacterial and Anti-Viral Activity}

Antibacterial and anti-viral agents kill or slow down the action of bacteria and viruses without inflicting any damage to the surrounding cells and tissues. Up until now, many compounds with the characteristics mentioned above have been found. In this connection, phenolics have also been shown to be potent antibacterial and anti-viral agents. For instance, phenolics constrained the growth and proliferation of hepatitis $\mathrm{C}$ virus (HCV); this virus is a primary blood-borne pathogen causing liver cirrhosis and hepatocellular carcinoma (HCC), thus inhibiting infection in primary human hepatocytes [42]. Kang et al. [43] reported that gallic acid and its derivatives attenuate the growth of cariogenic and periodontopathic bacteria. Gallic acid and methyl gallate also exhibited strong antibacterial and antiviral potential against Salmonella [44]. Kane et al. [63] stated inhibitory activity of gallic acid and methyl gallate against herpes viruses. They argued that the attachment of these phenolics to the virus proteins may interfere with their invasion of cells. Lin et al. [50] reported the suppression of virus type-1 infection of (+)-epigallocatechin 3-O-gallate. Moreover, phenolics such as stilbenes, tannins, and isoflavones inhibited the growth of fungi, yeasts, and viruses as well as bacteria such as Salmonella, Clostridium, Bacillus, and E. coli [64-66]. 


\subsection{Other Bioactivities of Phenolics}

Aside from anticancer, anti-inflammation, and antibacterial/-virus potential, a variety of clinical trials have established other beneficial bioactivities of phenolics. Ferulic acid alleviated angina pectoris and hypertension and is used as a traditional medicine in China [46]. Additionally, ferulic acid reduces the incidence of type 2-diabetes, cardiovascular disease, and neurodegenerative diseases $[34,45,67]$. Chlorogenic and caffeic acids inhibit the formation of mutagenic and carcinogenic $\mathrm{N}$-nitroso compounds [47]. Chao et al. [60] tested the effect of caffeic and ellagic acid on the suppression of diabetic kidney diseases of the rat. The intake of those phenolic acids for 12 weeks significantly reduced the levels of urinary glycated albumin, sorbitol, and fructose as well as suppression of sorbitol dehydrogenase activity. Flavonoids have also shown powerful bioactivities. For instance, catechins and their derivatives relieved degenerative diseases and brain aging processes. In addition, they are verified as strong neuroprotective chemicals that are useful for preventing Parkinson's and Alzheimer's diseases $[48,49,68,69]$. Catechin is also an effective agent that retards the development of atheromatous lesion [70]. Kaempferol is a potent neuroprotection agent by attenuating caspases cleavage and apoptotic nuclei, followed by guarding SH-SY5Y cells and important neurons from rotenone toxicity [53]. Trivedi et al. [51] reported the anti-osteoclastogenic effect of kaempferol, as well as its interference in the formation of adipocyte in bone marrow cells (BMCs). Quercetin revealed blood pressure-lowering effect by displaying antioxidant potential, inhibitory activity against angiotensin-converting enzyme (ACE), and enhanced endothelium-dependent and -independent function [71]. Quercetin limits the incidence of coronary heart disease by attenuating the expression of metalloproteinase 1, and they also interfere with the accumulation of plaques in the artery wall [72]. Resveratrol represses cyclooxygenase 1 activity, leading to a reduction in the accumulation of platelets [73], and exhibits anti-diabetes potential by modulating SIRT1, which contributes to the homeostasis of blood sugar content in diabetic rats [74]. Polyphenols such as (+)catechin, (-)epicatechin, isoflavones, tannic acid, and chlorogenic acid have also revealed anti-diabetes potential by reducing the intestinal transport of glucose through S-Glut-1 [75]. The consumption of genistein improved the function of the lung in asthmatic patients [76]. Moreover, isoflavones such as genistein and daidzein enhanced bone mineral density in ovariectomized rats [77]. Theaflavins, which are abundant in black tea, restrained the invasion of HIV-1 cells into the target cells, showing inhibitory activity against HIV-1 infection [78]. Theaflavin derivatives such as theaflavin-digallate and theaflavin-gallate prevented Severe Acute Respiratory Syndrome (SARS) coronavirus by inhibiting the chymotrypsin activity that plays a significant function in viral multiplication [78]. Tsuda et al. [79] stated that anthocyanidins, which are referred to as an efficient modulator of the metabolism of adipose tissue, showed strong potential for reducing obesity, inhibiting dysfunction of fat cells, and attenuating fat accumulation in adipose cells. In addition, anthocyanidins suppressed lipid oxidation and ameliorated the incidence of inflammation by inhibiting cyclooxygenase (COX)- 1 and -2 [80]. Tannins exert different health-beneficial effects such as enhancing blood clotting, reducing blood pressure, dropping serum lipid level, producing liver necrosis, and modulating immune responses [81,82].

\section{Bioactivities of Phenolic Extracts from Natural Origin}

\subsection{Grains/Cereals}

Grains are rich in carbohydrates, lipids, and proteins, together with a high level of phytochemicals such as phenolics. Some phytochemicals exhibit direct biological activities, i.e., anticancer, anti-inflammatory, and antibacterial potential, whereas others may function indirectly by acting as the cofactor of antioxidant enzymes. Epidemiological evidence has shown that regular consumption of grains and cereals reduces the incidence of chronic ailments such as vascular disease, type 2 diabetes, and different types of cancer [83-85]. In this section, the bioactivities of phenolic extracts of grains and cereals are discussed by focusing on their preventive effects on chronic ailments (Table 2). 
Table 2. Bioactivities of phenolic extract from natural origins. LDL: low density lipoprotein; SOD: superoxide dismutase; CAT: catalase.

\begin{tabular}{|c|c|c|c|}
\hline & Phenolics & Bioactivities & References \\
\hline \multicolumn{4}{|l|}{ Grains/Cereals } \\
\hline \multirow{4}{*}{ Black rice } & \multirow{4}{*}{$\begin{array}{l}\text { Flavones, tannin, } \\
\text { and anthocyanidins }\end{array}$} & Anti-atherosclerosis activity & {$[86]$} \\
\hline & & Antitumor activity & [87] \\
\hline & & Anti-allergic activity & [88] \\
\hline & & Anti-fatigue and hypoxia tolerance & [89] \\
\hline Millet & $\begin{array}{l}\text { Phenolic acids, flavonoids, } \\
\text { and proanthocyanidins }\end{array}$ & $\begin{array}{l}\text { Inhibition of radical-induced DNA } \\
\text { scission and the oxidation of human } \\
\text { LDL cholesterol }\end{array}$ & [90] \\
\hline Wild rice & Phenolics & Enhancing SOD and CAT activities & [91] \\
\hline Rye & Ferulic acid & $\begin{array}{l}\text { Decrease in mtDNA 8-OhdG levels in } \\
\text { liver, kidneys, and pancreas }\end{array}$ & [92] \\
\hline \multicolumn{4}{|l|}{ Legumes/Seeds } \\
\hline Grape seed & Kaempferol and quercetin & Inhibition of lipase activity & [93] \\
\hline Pea (seed coats) & Phenolic acids and flavonoids & Anticancer & [94] \\
\hline Flaxseed & Lignan & Anticancer & [95] \\
\hline Lentil & $\begin{array}{l}\text { Phenolic acids, flavonoids, } \\
\text { and proanthocyanidins }\end{array}$ & $\begin{array}{l}\text { Inhibition of radical-induced DNA } \\
\text { scission and the oxidation of human } \\
\text { LDL cholesterol }\end{array}$ & [15] \\
\hline Black soybean & Anthocyanins & Anti-inflammation & [96] \\
\hline Navy and black bean & $\begin{array}{l}\text { Phenolic acids, flavonoids, } \\
\text { and anthocyanins }\end{array}$ & Anti-inflammation & [97] \\
\hline Red bean & Catechin-7- $\beta$-D-glucopyranoside & Anti-inflammation & [98] \\
\hline \multicolumn{4}{|l|}{ Fruits } \\
\hline Pomegranate juice & $\begin{array}{l}\text { Phenolic acids, flavonoids, } \\
\text { and proanthocyanidins }\end{array}$ & $\begin{array}{c}\text { Anticancer } \\
\text { Anti-inflammation }\end{array}$ & $\begin{array}{c}{[99]} \\
{[100]}\end{array}$ \\
\hline Blackberry & $\begin{array}{l}\text { Phenolic acids, flavonoids, } \\
\text { and tannins }\end{array}$ & Anticancer & [101] \\
\hline Indian gooseberry & Phenolic acids and flavonoids & Anticancer & [101] \\
\hline Orange & Flavonoids & Anticancer (breast cancer) & $\begin{array}{l}{[102]} \\
{[103]}\end{array}$ \\
\hline Apple & $\begin{array}{l}\text { Catechin, procyanidins, } \\
\text { and phloridzin }\end{array}$ & Anticancer & [104] \\
\hline Citrus & Narirutin & Anti-inflammation & [105] \\
\hline
\end{tabular}

Black rice phenolics which includes a high level of anthocyanidins, namely cyanidin 3-glucoside, malvidin 3-galactoside, peonidin3-glucoside, and pelargonidin 3,5-diglucoside, efficiently alleviated the incidence of chronic diseases such as antiatherosclerosis, antitumor, antiallergic, and, antifatigue activities as well as improving hypoxia tolerance [86-89]. Chandrasekara and Shahidi [90] found a dose-dependent inhibitory capacity against DNA scission and oxidation of LDL cholesterol for ferulic and $p$-coumaric acids that were isolated from millets. Surendrian et al. [91] reported that wild rice enhanced the activity of antioxidant enzymes such as superoxide dismutase (SOD) and catalase (CAT) due to the presence of phenolics in a mouse model system. Moreover, the ferulic acid in rye resulted in a remarkable decrease of mtDNA 8-OhdG levels in the liver, kidneys, and pancreas in mice [92].

\subsection{Legumes/Seeds}

Legumes and seeds are rich in proteins and dietary fiber as well as other nutrients and antioxidant compounds, which leads to their beneficial health effects in preventing aging, strengthening immunity, lowering cholesterol levels, and reducing cardiovascular diseases. Apart from the aforementioned 
compounds, legumes/seeds contain a high level of phenolics including phenolics acids, flavonoids, and proanthocyanidins, which are responsible for the efficient bioactivities. The hull portion of legumes and seeds possesses a higher content of phenolic compounds than the corresponding dehulled parts due to the presence of phenolic-containing cells such as epidermis, hypodermis, chlorenchyma, palisade, parenchyma, and endothelium cells [21]. The vacuole, which is a key organ of a plant cell, reserves the largest volume of water of the cells along with plant metabolites such as phenolics and organic acids. The high level of phenolics in legumes and seeds contributes remarkable bioactivities to products. For instance, peas contain a variety of phenolics such as gallic acid, epigallocatechin, naringenin, and apigenin, which results in their potential chemopreventive and complementary properties in cancer therapy [94]. Sergent et al. [93] have demonstrated the lipase inhibitory effect of epigallocatechin-3-gallate, kaempferol, and quercetin extracted from grape seeds. Thompson et al. [95] reported that lignans from flaxseed had protective potential against chemically induced carcinogenesis in animal models. Alshikh et al. [15] isolated free, esterified, and insoluble-bound phenolics from selected lentils and these showed inhibitory activity against cupric ion-induced human LDL peroxidation and peroxyl radical-induced DNA strand breakage. In addition, anthocyanins in black soybeans displayed anti-inflammatory activity in a rat model system [96], and the phenolic acids, flavonoids, and anthocyanins of navy and black beans suppressed the mRNA expression of colonic inflammatory cytokines such as IL-6, IL-9, IFN-g, and IL-17A in a mouse model of acute colitis [97]. Ethanol extract of red beans containing catechin-7- $\beta$-D-glucopyranoside efficiently inhibited nitric oxide (NO) production in both in vitro and in vivo models [98].

\subsection{Fruits/Vegetables}

Fruits contain a high level of phenolics and have shown excellent bioactivities such as anticancer and anti-inflammatory activities. Patterson and Murray [99] have reported that regular consumption of pomegranate juice, which contains punicalagin A, punicalagin B, and ellagic acid, as well as anthocyanins such as cyanidin-diglucoside, pelargonidin, delphinidin-diglucoside, and cyanidin-pentoside, suppresses the growth of cancer cells by reducing total hepatic cytochromes P450 (CYP) content in a mouse model system. In addition, pomegranate juice attenuated inflammatory cytokine expression, followed by an anti-inflammation effect [100]. The chronic consumption of oranges reduced the risk of breast cancer due to the presence of flavonoids [102,103]. Serra et al. [104] found several phenolics such as catechin, procyanidins (B1 and B2), phloridzin, and epicatechin in apples, and these phenolics showed anticarcinogenic potential. Moreover, phenolics in Indian gooseberry such as myricetin, quercetin, gallic acid, ellagic acid, and tannins such as glucogallin (1-O-galloyl- $\beta$-D-glucose), corilagin, pedunculagin displayed anticancer potential [101]. Phenolics in blackberry such as cyanidin-3-glucoside, cyanidin-3-galactoside, malvidin-3-O-arabinoside, and delphinidin derivatives also exhibited anticancer activity [101]. Citrus inhibited the release of pro-inflammatory cytokines such as NO, prostaglandin E2 (PGE2), IL-1b, and TNF- $\alpha$ in RAW 264.7 macrophages model system [105]. Resveratrol, found in grapes and some blueberries, has been proven to enhance cognition in rodents [106]. Moreover, phenolics in strawberries display antioxidant defense by suppressing the NF- $\mathrm{kB}$ signalling pathway [107]. Some polyphenols in oranges contribute to preventing cardiovascular disease and inflammation [108]. Thus, fruits have been proven to be excellent foods for preventing and relieving chronic ailments due to their high content of phenolics.

Vegetables also contain a variety of phenolics; for instance, parsley and celery possess apigenin, chrysin, and luteolin, and broccoli has a considerable amount of quercetin, kaempferol, and myricetin, leading to their potent inhibition of inflammation and different types of cancers such as gastric, breast, and prostate [109].

\section{Conclusions}

In this review, the bioactivities of phenolics as such or present in extracts from natural origin such as grains, cereals, legumes, seeds, and fruits were summarized. A large body of epidemiological 
evidence exists on their protective effects against a number of chronic ailments such as cancer, inflammatory diseases, and bacterial disorders, as well as reducing diabetes, cardiovascular and neurodegenerative diseases. Moreover, the inhibition of Parkinson's and Alzheimer's diseases, as well as anti-analgesic, anti-allergic, cardioprotective, and anti-diabetic activities have also been documented for food phenolics. Thus, it is expected that phenolic compounds serve as useful natural bioactive and nutraceutical agents for preventing/inhibiting adult ailments.

Author Contributions: F.S. and J.Y. composed this review paper.

Acknowledgments: We are grateful to the Natural Science and Engineering Research Council (NSERC) of Canada for financial support.

Conflicts of Interest: The authors declare no conflict of interest.

\section{References}

1. Cheynier, V.; Comte, G.; Davies, K.M.; Lattanzio, V.; Martens, S. Plant phenolics: Recent advances on their biosynthesis, genetics and ecophysiology. Plant Physiol. Biochem. 2013, 72, 1-20. [CrossRef] [PubMed]

2. Manach, C.; Scalbert, A.; Morand, C.; Rémésy, C.; Jiménez, L. Polyphenols: Food sources and bioavailability. Am. J. Clin. Nutr. 2004, 79, 727-747. [CrossRef] [PubMed]

3. Nardini, M.; Cirillo, E.; Natella, F.; Scaccini, C. Absorption of phenolic acids in humans after coffee consumption. J. Agric. Food Chem. 2002, 50, 5735-5741. [CrossRef] [PubMed]

4. Kawabata, J.; Mishima, M.; Kurihara, H.; Mizuntani, J.; Kobophenol, B. A tetrastilbene from Carex pumila. Phytochemistry 1991, 2, 645-647. [CrossRef]

5. Yamada, M.; Hayashi, K.I.; Hayashi, H.; Ikeda, S.; Hoshino, T.; Tsutsui, K.; Tsutsui, K.; Iinuma, M.; Nozaki, H. Stilbenoids from Kobresia nepalensis exhibiting DNA topoisomerase II inhibition. Phytochemistry 2006, 67, 307-313. [CrossRef] [PubMed]

6. Baur, J.A.; Sinclair, D.A. Therapeutic potential of resveratrol: The in vivo evidence. Nat. Rev. Drug Discov. 2006, 5, 493-506. [CrossRef] [PubMed]

7. Salem, S.; Shafique, A.; Dore, S. Protective effects of resveratrol in age-related neurodegenerative diseases and gene regulatory action. In Oxidative Stress and Diseases: Resveratrol in Health and Disease; Aggarwal, B.B., Shishodia, S., Packer, L., Eds.; Taylor \& Francis Group: Boca Raton, FL, USA, 2006; pp. 499-518.

8. Han, Y.; Bastianoetto, S.; Quirion, R. Neuroprotective effects of resveratrol. In Oxidative Stress and Diseases: Resveratrol in Health and Disease; Aggarwal, B.B., Shishodia, S., Packer, L., Eds.; Taylor \& Francis Group: Boca Raton, FL, USA, 2006; pp. 619-630.

9. Lacy, A.; O'Kennedy, R. Studies on coumarins and coumarin-related compounds to determine their therapeutic role in the treatment of cancer. Curr. Pharm. Des. 2004, 10, 3797-3811. [CrossRef] [PubMed]

10. Jain, P.K.; Joshi, H. Coumarin: Chemical and pharmacological profile. J. Appl. Pharm. Sci. 2012, 2, 236-240.

11. Lee, S.J.; Lee, U.S.; Kim, W.J.; Moon, S.K. Inhibitory effect of esculetin on migration, invasion and matrix metalloproteinase-9 expression in TNF- $\alpha$-induced vascular smooth muscle cells. Mol. Med. Rep. 2011, 4, 337-341. [PubMed]

12. Nitiema, L.W.; Savadogo, A.; Simpore, J.; Dianou, D.; Traore, A.S. In vitro antimicrobial activity of some phenolic compounds (coumarin and quercetin) against gastroenteritis bacterial strains. Int. J. Microbiol. Res. 2012, 3, 183-187.

13. Kostova, I.; Bhatia, S.; Grigorov, P.; Balkansky, S.; Pramar, V.S.; Prasad, A.K.; Saso, L. Coumarins as antioxidants. Curr. Med. Chem. 2011, 18, 3929-3951. [CrossRef] [PubMed]

14. Anand, P.; Singh, B.; Singh, N. A review on coumarins as acetylcholinesterase inhibitors for Alzheimer's disease. Bioorgan. Med. Chem. 2012, 20, 1175-1180. [CrossRef] [PubMed]

15. Alshikh, N.; de Camargo, A.C.; Shahidi, F. Phenolics of selected lentil cultivars: Antioxidant activities and inhibition of low-density lipoprotein and DNA damage. J. Funct. Foods 2015, 18, 1022-1038. [CrossRef]

16. De Freitas, V.; Glories, Y. Concentration and compositional changes of procyanidins in grape seeds and skin of white Vitis Vinifera varieties. J. Sci. Food Agric. 1999, 79, 1601-1606. [CrossRef]

17. Pérez-Ilzarbe, F.J; Martinez, V.; Hernández, T.; Estrella, I. Liquid chromatographic determination of apple pulp procyanidins. J. Liq. Chromatogr. 1992, 15, 637-646. [CrossRef] 
18. Saito, M.; Hosoyama, H.; Ariga, T.; Kataoda, S.; Yamaji, N. Antiulcer activity of grape seed extract and procyanidins. J. Agric. Food Chem. 1998, 46, 1460-1464. [CrossRef]

19. Castillo, J.; Benavente-Garcia, O.; Lorente, J.; Alcaraz, M.; Redondo, A.; Ortunõ, A.; del Rio, J.A. Antioxidant activity and radioprotective effects against chromosomal damage induced in vivo by $\mathrm{X}$-rays of flavan-3-ols (procyanidins) froma grape seeds (Vitis Vinifera): Comparative study versus other phenolic and organic compounds. J. Agric. Food Chem. 2000, 48, 1738-1745. [CrossRef] [PubMed]

20. Ricardo da Silva, J.M.; Darmon, N.; Fernández, U.; Mitjavila, S. Oxygen free radical scavenger capacity in aqueous models of different procyanidins from grape seeds. J. Agric. Food Chem. 1991, 39, 1549-1552. [CrossRef]

21. Shahidi, F.; Yeo, J.D. Review: Insoluble-bound phenolics in foods. Molecules 2016, 21, 1216. [CrossRef] [PubMed]

22. Shahidi, F.; Naczk, M. Phenolics in Food and Nutraceuticals; CRC Press Inc.: Boca Raton, FL, USA, 2004; pp. 13-141.

23. Podsedek, A.; Redzynia, M.; Klewicka, E.; Koziołkiewicz, M. Matrix effects on the stability and antioxidant activity of red cabbage anthocyanins under simulated gastrointestinal digestion. BioMed Res. Int. 2014, 2014, 1-11. [CrossRef] [PubMed]

24. Scalbert, A.; Williamson, G. Dietary intake and bioavailability of polyphenols. J. Nutr. 2000, 130, $2073-2085$. [CrossRef] [PubMed]

25. Adom, K.K.; Liu, R.H. Antioxidant activity of grains. J. Agric. Food Chem. 2002, 50, 6182-6187. [CrossRef] [PubMed]

26. Andreasen, M.F.; Kroon, P.A.; Williamson, G.; Garcia-Conesa, M.T. Intestinal release and uptake of phenolic antioxidant diferulic acids. Free Radic. Biol. Med. 2001, 31, 304-314. [CrossRef]

27. Gibson, G.; Roberfroid, M. Dietary modulation of the human colonic microbiota: Introducing the concept of prebiotics. J. Nutr. 1995, 125, 1401-1412. [PubMed]

28. Yi, W.; Fisher, J.; Krewer, G.; Akoh, C.C. Phenolic compounds from blueberries can inhibit colon cancer cell proliferation and induce apoptosis. J. Agric. Food Chem. 2005, 53, 7320-7329. [CrossRef] [PubMed]

29. Anantharaju, P.G.; Gowda, P.C.; Vimalambike, M.G.; Madhunapantula, S.V. An overview on the role of dietary phenolics for the treatment of cancers. Nutr. J. 2016, 15, 1-16. [CrossRef] [PubMed]

30. Yeh, R.D.; Chen, J.C.; Lai, T.Y.; Yang, J.S.; Yu, C.S.; Chiang, J.H.; Lu, C.C.; Yang, S.T.; Yu, C.C.; Chang, S.J.; et al. Gallic acid induces $\mathrm{G}(0) / \mathrm{G}(1)$ phase arrest and apoptosis in humanleukemia HL-60 cells through inhibiting cyclin D and E, and activating mitochondria-dependent pathway. Anticancer Res. 2011, 31, 2821-2832. [PubMed]

31. Veluri, R.; Singh, R.P.; Liu, Z.; Thompson, J.A.; Agarwal, R.; Agarwal, C. Fractionation of grape seed extract and identification of gallic acid as one of the major active constituents causing growth inhibition and poptotic death of DU-145 human prostate carcinoma cells. Carcinogenes 2006, 27, 1445-1453. [CrossRef] [PubMed]

32. Kamatham, S.; Kumar, N.; Gudipalli, P. Isolation and characterization of gallic acid and methylgallate from the seed coats of Givotia rottleriformis Griff. and their anti-proliferative effect on human epidermoidcarcinoma A431 cells. Toxicol. Rep. 2015, 2, 520-529. [CrossRef] [PubMed]

33. Fahrioğlu, U.; Dodurga, Y.; Elmas, L.; Seçme, M. Ferulic acid decreases cell viability and colony formation while inhibiting migration of MIA PaCa-2 human pancreatic cancer cells in vitro. Gene 2016, 576, 476-482. [CrossRef] [PubMed]

34. Eitsuka, T.; Tatewaki, N.; Nishida, H.; Kurata, T.; Nakagawa, K.; Miyazawa, T. Synergistic inhibition of cancer cell proliferation with a combination of delta-tocotrienol and ferulic acid. Biochem. Biophys. Res. Commun. 2014, 453, 606-611. [CrossRef] [PubMed]

35. Choi, Y.E.; Park, E. Ferulic acid in combination with PARP inhibitor sensitizes breast cancer cells as chemotherapeutic strategy. Biochem. Biophys. Res. Commun. 2015, 458, 520-524. [CrossRef] [PubMed]

36. Janicke, B.; Hegardt, C.; Krogh, M.; Onning, G.; Akesson, B.; Cirenajwis, H.M.; Oredsson, S.M. The antiproliferative effect of dietary fiber phenolic compounds ferulic acid and p-coumaric acid on the cell cycle of Caco-2 cells. Nutr. Cancer 2011, 63, 611-622. [CrossRef] [PubMed]

37. Fang, H.Y.; Wang, H.M.; Chang, K.F.; Hu, H.T.; Hwang, L.J.; Fu, T.F.; Chen, B.H. Feruloyl-L-arabinose attenuates migration, invasion and production of reactive oxygen species in H1299 lung cancer cells. Food Chem. Toxicol. 2013, 58, 459-466. [CrossRef] [PubMed] 
38. Panat, N.A.; Singh, B.G.; Maurya, D.K.; Sandur, S.K.; Ghaskadbi, S.S. Troxerutin, a natural flavonoid binds to DNA minor groove and enhances cancer cell killing in response to radiation. Chem. Biol. Interact. 2016, 251, 34-44. [CrossRef] [PubMed]

39. Watanabe, N.; Hirayama, R.; Kubota, N. The chemopreventive flavonoid apigenin confers radiosensitizing effect in human tumor cells grown as monolayers and spheroids. J. Radiat. Res. 2007, 48, 45-50. [CrossRef] [PubMed]

40. Leung, H.W.C.; Lin, C.J.; Hour, M.J.; Yang, W.H.; Wang, M.Y.; Lee, H.Z. Kaempferol induces apoptosis in human lung non-small carcinoma cells accompanied by an induction of antioxidant enzymes. Food Chem. Toxicol. 2007, 45, 2005-2013. [CrossRef] [PubMed]

41. Nirmala, P.; Ramanathan, M. Effect of myricetin on 1,2 dimethylhydrazineinduced rat colon carcinogenesis. J. Exp. Ther. Oncol. 2011, 9, 101-108. [PubMed]

42. Hsu, W.C.; Chang, S.P.; Lin, L.C.; Li, C.L.; Richardson, C.D.; Lin, C.C.; Lin, L.T. Limonium sinense and gallic acid suppress hepatitis $C$ virus infection by blocking early viral entry. Antivir. Res. 2015, 118, 139-147. [CrossRef] [PubMed]

43. Kang, M.S.; Oh, J.S.; Kang, I.C.; Hong, S.J.; Choi, C.H. Inhibitory effect of methyl gallate and gallic acid on oral bacteria. J. Microbiol. 2008, 46, 744-750. [CrossRef] [PubMed]

44. Choi, J.G.; Kang, O.H.; Lee, Y.S.; Oh, Y.C.; Chae, H.S.; Jang, H.J.; Kim, J.H.; Sohn, D.H.; Shin, D.W.; Park, H.; et al. In vitro activity of methyl gallate isolated from galla rhois alone and in combination with ciprofloxacin against clinical isolates of salmonella. J. Microbiol. Biotechnol. 2008, 18, 1848-1852. [PubMed]

45. Narasimhan, A.; Chinnaiyan, M.; Karundevi, B. Ferulic acid regulates hepatic GLUT2 gene expression in high fat and fructose-induced type-2 diabetic adult male rat. Eur. J. Pharmacol. 2015, 761, 391-397. [CrossRef] [PubMed]

46. Hou, Y.Z.; Zhao, G.R.; Yang, J.; Yuan, Y.J.; Zhu, G.G.; Hiltunen, R. Protective effect of Ligusticum chuanxiong and Angelica sinensis on endothelial cell damage induced by hydrogen peroxide. Life Sci. 2004, 75, 1775-1786. [CrossRef] [PubMed]

47. Mennen, L.I.; Walker, R.; Bennetau-Pelissero, C.; Scalbert, A. Risks and safety of polyphenol consumption. Am. J. Clin. Nutr. 2005, 81, 326-329. [CrossRef] [PubMed]

48. Weinreb, O.; Mandel, S.; Amit, T.; Moussa, B.; Youdim, H. Neurological mechanisms of green tea polyphenols in Alzheimer's and Parkinson's diseases. J. Nutr. Biochem. 2004, 15, 506-516. [CrossRef] [PubMed]

49. Dai, Q.; Borenstein, A.R.; Wu, Y. Fruit and vegetable juices and Alzheimer's disease: The Kame project. Am. J. Clin. Nutr. 2006, 119, 751-759. [CrossRef] [PubMed]

50. Lin, L.C.; Kuo, Y.C.; Chou, C.J. Anti-herpes simplex virus type-1 flavonoids and a new flavanone from the root of Limonium sinense. Planta Med. 2000, 66, 333-336. [CrossRef] [PubMed]

51. Trivedi, R.; Kumar, S.; Kumar, A.; Siddiqui, J.A.; Swarnkar, G.; Gupta, V.; Kendurker, A.; Dwivedi, A.K.; Romero, J.R.; Chattopadhyay, N. Kaempferol has osteogenic effect in ovariectomized adult Spraguee Dawley rats. Mol. Cell. Endocrinol. 2008, 289, 85-93. [CrossRef] [PubMed]

52. Devi, K.P.; Malar, D.S.; Nabavi, S.F.; Sureda, A.; Xiao, J.; Nabavi, S.M. Kaempferol and inflammation: From chemistry to medicine. Pharmacol. Res. 2015, 99, 1-10. [CrossRef] [PubMed]

53. Filomeni, G.; Graziani, I.; De Zio, D.; Dini, L.; Centonze, D.; Rotilio, G.; Ciriolo, M.R. Neuroprotection of kaempferol by autophagy in models of rotenone-mediated acute toxicity: Possible implications for Parkinson's disease. Neurobiol. Aging 2012, 33, 767-785. [CrossRef] [PubMed]

54. Calderon-Montano, J.M.; Burgos-Moron, E.; Perez-Guerrero, C.; Lopez-Lazaro, M. A review on the dietary flavonoid kaempferol. Mini-Rev. Med. Chem. 2011, 11, 298-344. [CrossRef] [PubMed]

55. Ju, S.M.; Kang, J.G.; Bae, J.S.; Pae, H.O.; Lyu, Y.S.; Jeon, B.H. The flavonoid apigenin ameliorates cisplatin-induced nephrotoxicity through reduction of p53 activation and promotion of PI3K/Akt pathway in human renal proximal tubular epithelial cells. Evid. Based Complement. Altern. Med. 2015, 1-9. [CrossRef] [PubMed]

56. Chtourou, Y.; Aouey, B.; Aroui, S.; Kebieche, M.; Fetoui, H. Anti-apoptotic and anti-inflammatory effects of naringin on cisplatin-induced renal injury in the rat. Chem. Biol. Interact. 2016, 243, 1-9. [CrossRef] [PubMed]

57. Kamel, K.M.; El-Raouf, A.; Ola, M.; Metwally, S.A.; El-Latif, A.; Hekma, A.; Elsayed, M.E. Hesperidin and rutin, antioxidant citrus flavonoids, attenuate cisplatin-induced nephrotoxicity in rats. J. Biochem. Mol. Toxic. 2014, 28, 312-319. [CrossRef] [PubMed] 
58. Wang, B.S.; Huang, G.J.; Lu, Y.H.; Chang, L.W. Anti-inflammatory effects of an aqueous extract of Welsh onion green leaves in mice. Food Chem. 2013, 138, 751-756. [CrossRef] [PubMed]

59. Pragasam, S.J.; Venkatesan, V.; Rasool, M. Immunomodulatory and anti-inflammatory effect of p-coumaric acid, a common dietary polyphenol on experimental inflammation in rats. Inflammation 2013, 36, 169-176. [CrossRef] [PubMed]

60. Chao, C.Y.; Mong, M.C.; Chan, K.C.; Yin, M.C. Anti-glycative and anti-inflammatory effects of caffeic acid and ellagic acid in kidney of diabetic mice. Mol. Nutr. Food Res. 2010, 54, 388-395. [CrossRef] [PubMed]

61. Da Cunha, F.M.; Duma, D.; Assreuy, J.; Buzzi, F.C.; Niero, R.; Campos, M.M.; Calixto, J.B. Caffeic acid derivatives: In vitro and in vivo anti-inflammatory properties. Free Radic. Res. 2004, 38, 1241-1253. [CrossRef] [PubMed]

62. Hamalainen, M.; Nieminen, R.; Vuorela, P.; Heinonen, M.; Moilanen, E. Anti-inflammatory effects of flavonoids: Genistein, kaempferol, quercetin, and daidzein inhibit STAT-1 and NF- $\mathrm{B}$ activations, whereas flavone, isorhamnetin, naringenin, and pelargonidin inhibit only NF- $\mathrm{kB}$ activation along with their inhibitory effect on iNOS expression and NO production in activated macrophages. Mediat. Inflamm. 2007. [CrossRef]

63. Kane, C.J.; Menna, J.H.; Sung, C.C.; Yeh, Y.C. Methyl gallate, methyl-3,4,5-trihydoxybenzoate, is a potent and highly specific inhibitor of herpes simplex virus in vitro. II. Antiviral activity of methyl gallate and its derivatives. Biosci. Rep. 1988, 8, 95-102. [CrossRef] [PubMed]

64. Cabrera, C.; Artacho, R.; Giménez, R. Beneficial effects of green tea. J. Am. Coll. Nutr. 2006, 25, 79-99. [CrossRef] [PubMed]

65. Alvesalo, J.; Vuorela, H.; Tammela, P.; Leinonen, M.; Saikku, P.; Vuorela, P. Inhibitory effect of dietary phenolic compounds on Chlamydia pneumoniae in cell cultures. Biochem. Pharmacol. 2006, 71, 735-741. [CrossRef] [PubMed]

66. Morinaga, N.; Iwamaru, Y.; Yahiro, K.; Tagashira, M.; Moss, J.; Noda, M. Differential activities of plant polyphenols on the binding and internalization of cholera toxin in vero cells. J. Biol. Chem. 2005, 280, 23303-23309. [CrossRef] [PubMed]

67. Mancuso, C.; Santangelo, R. Ferulic acid: Pharmacological and toxicological aspects. Food Chem. Toxicol. 2014, 65, 185-195. [CrossRef] [PubMed]

68. Yang, F.; De Villiers, W.J.; McClain, C.J.; Varilek, G.W. Green tea polyphenols block endotoxin-induced tumor necrosis factor-production and lethality in a murine model. J. Nutr. 1998, 128, 2334-2340. [CrossRef] [PubMed]

69. Tedeschi, E.; Menegazzi, M.; Yao, Y.; Suzuki, H.; Forstermann, U.; Kleinert, H. Green tea inhibits human inducible nitric-oxide synthase expression by down-regulating signal transducer and activator of transcription-1 $\alpha$ activation. Mol. Pharmacol. 2004, 65, 111-120. [CrossRef] [PubMed]

70. Maeda, K.; Kuzuya, M.; Cheng, X.W.; Asai, T.; Kanda, S.; Tamaya-Mori, N.; Sasaki, T.; Shibata, T.; Iguchi, A. Green tea catechins inhibit the cultured smooth muscle cell invasion through the basement barrier. Atherosclerosis 2003, 166, 23-30. [CrossRef]

71. Larson, A.J.; Symons, J.D.; Jalili, T. Therapeutic potential of quercetin to decrease blood pressure: Review of efficacy and mechanisms. Adv. Nutr. 2012, 3, 39-46. [CrossRef] [PubMed]

72. García-Lafuente, A.; Guillamón, E.; Villares, A.; Rostagno, M.A.; Martínez, J.A. Flavonoids as anti-inflammatory agents: Implications in cancer and cardiovascular disease. Inflamm. Res. 2009, 58, 537-552. [CrossRef] [PubMed]

73. Pirola, L.; Frojdo, S. Resveratrol: One molecule, many targets. IUBMB Life 2008, 60, 323-332. [CrossRef] [PubMed]

74. Milne, J.C.; Lambert, P.D.; Schenk, S.; Carney, D.P.; Smith, J.J.; Gagne, D.J. Small molecule activators of SIRT1 as therapeutics for the treatment of type 2 diabetes. Nature 2007, 450, 712-716. [CrossRef] [PubMed]

75. Matsui, T.; Ueda, T.; Oki, T.; Sugita, K.; Terahara, N.; Matsumoto, K. $\alpha$-Glucosidase inhibitory action of natural acylated anthocyanins. J. Agric. Food Chem. 2001, 49, 1952-1956. [CrossRef] [PubMed]

76. Smith, L.J.; Holbrook, J.T.; Wise, R.; Blumenthal, M.; Dozor, A.J.; Mastronarde, J. Dietary intake of soy genistein is associated with lung function in patients with asthma. J. Asthma 2004, 41, 833-843. [CrossRef] [PubMed]

77. Nakajima, D.; Kim, C.S.; Oh, T.W.; Yang, C.Y.; Naka, T.; Igawa, S.; Ohta, F. Suppressive effects of genistein dosage and resistance exercise on bone loss in ovariectomized rats. J. Physiol. Anthropol. Appl. Hum. Sci. 2001, 20, 285-291. [CrossRef] 
78. Sharma, V.; Rao, L.J. A thought on the biological activities of black tea. Crit. Rev. Food Sci. Nutr. 2009, 49, 379-404. [CrossRef] [PubMed]

79. Tsuda, T.; Horio, F.; Uchida, K.; Hiromitsu, A.; Osawa, T. Dietary cyanidin 3-O- $\beta$-D-glucoside-rich purple corn color prevents obesity and ameliorates hyperglycemia in mice. J. Nutr. 2003, 133, 2125-2130. [CrossRef] [PubMed]

80. Seeram, N.P.; Cichewicz, R.H.; Chandra, A.; Nair, M.G. Cyclooxygenase inhibitory and antioxidant compounds from crabapple fruits. J. Agric. Food Chem. 2003, 51, 1948-1951. [CrossRef] [PubMed]

81. Chung, K.T.; Wong, T.Y.; Wei, C.I.; Huang, Y.W.; Lin, Y. Tannins and human health: A review. Crit. Rev. Food Sci. Nutr. 1998, 38, 421-464. [CrossRef] [PubMed]

82. Okuda, T. Tannins, a new family of bio-active natural organic compounds questions and answers. J. Pharm. Soc. Jpn. 1995, 115, 81-100. [CrossRef]

83. Liu, S.; Manson, J.E.; Stamfer, M.J.; Hu, F.B.; Giovannucci, E.; Colditz, G.A. A prospective study of whole-grain intake and risk of type 2 diabetes mellitus in US women. Am. J. Public Health 2000, 90, 1409-1415. [PubMed]

84. Lloyd, B.J.; Siebenmorgen, T.J.; Beers, K.W. Effects of commercial processing on antioxidants in rice bran. Cereal Chem. 2000, 77, 551-555. [CrossRef]

85. Topping, D. Cereal complex carbohydrates and their contribution to human health. J. Cereal Sci. 2007, 46, 220-229. [CrossRef]

86. Chen, Q.; Ling, W.H.; Ma, J.; Mei, J. Effects of black and red rice on the formation of aortic plaques and blood lipids in rabbits. J. Hyg. Res. 2000, 29, 170-172.

87. Koide, T.; Kamei, H.; Hashimoto, Y.; Kojima, T.; Hasegawa, M. Antitumor effect of hydrolyzed anthocyanin from grape rinds and red rice. Cancer Biother. Radiopharm. 1996, 11, 273-277. [CrossRef] [PubMed]

88. Kim, H.M.; Kang, C.S.; Lee, E.H.; Shin, T.Y. The evaluation of the antianaphylactic effect of Oryza sativa L. subsp. hsien Ting in rats. Pharmacol. Res. 1999, 40, 31-36. [CrossRef] [PubMed]

89. Hu, Q.L. A research report on the pharmacologic test of black rice pigment. J. Wuhan Food Ind. Coll. 1997, 3, $10-12$.

90. Chandrasekara, A.; Shahidi, F. Bioactivities and antiradical properties of millet grains and hulls. J. Agric. Food Chem. 2011, 59, 9563-9571. [CrossRef] [PubMed]

91. Surendrian, G.; Goh, C.; Le, K.; Zhao, Z.; Askarian, F.; Othman, R.; Moghadasian, M.H. Wild rice (Zizania paplustris L.) prevents atherogenesis in LDL receptor knockout mice. Atherosclerosis 2013, 230, $284-292$. [CrossRef] [PubMed]

92. Hsieh, R.H.; Lien, L.M.; Lin, S.H.; Chen, C.W.; Cheng, H.J.; Cheng, H.H. Alleviation of oxidative damage in multiple tissues in rats with streptozotocin induced diabetes by rice bran oil supplementation. Ann. N. Y. Acad. Sci. 2005, 1042, 365-371. [CrossRef] [PubMed]

93. Sergent, T.; Vanderstraeten, J.; Winand, J.; Beguin, P.; Schneider, Y. Phenolic compounds and plant extracts as potential natural antiobesity substances. Food Chem. 2012, 135, 68-73. [CrossRef]

94. Stanisavljević, N.S.; Ilić, M.D.; Matić, I.Z.; Jovanović, Ž.S.; Čupić, T.; Dabić, D.Č.; Natić, M.M.; Tešić, Ž.L. Identification of phenolic compounds from seed coats of differently colored european varieties of pea (Pisum sativum L.) and characterization of their antioxidant and In vitro anticancer activities. Nutr. Cancer 2016, 68, 988-1000. [CrossRef] [PubMed]

95. Thompson, L.U.; Rickard, S.E.; Cheung, F.; Kenaschuk, E.O.; Obermeyer, W.R. Variability in anticancer lignan levels in flaxseed. Nutr. Cancer 1997, 27, 26-30. [CrossRef] [PubMed]

96. Sohn, D.W.; Bae, W.J.; Kim, H.S.; Kim, S.W.; Kim, S.W. The anti-inflammatory and antifibrosis effects of anthocyanin extracted from black soybean on a Peyronie disease rat model. Urology 2014, 84, 1112-1116. [CrossRef] [PubMed]

97. Zhang, C.; Monk, J.M.; Lu, J.T.; Zarepoor, L.; Wu, W.; Liu, R.; Pauls, K.P.; Wood, G.A.; Robinson, L.; Tsao, R.; et al. Cooked navy and black bean diets improve biomarkers of colon health and reduce inflammation during colitis. Br. J. Nutr. 2014, 111, 1549-1563. [CrossRef] [PubMed]

98. Park, S.; Choi, K.C.; Fang, M.; Lim, Y.C.; Jeon, Y.M.; Lee, J.C. Red bean extract reduces inflmmation and increases survival murine sepsis model. Food Sci. Biotechnol. 2011, 20, 1125-1131. [CrossRef]

99. Patterson, L.H.; Murray, G.I. Tumour cytochrome P450 and drugactivation. Curr. Pharm. Des. 2002, 8, 1335-1347. [CrossRef] [PubMed] 
100. Adams, L.S.; Seeram, N.P.; Aggarwal, B.B.; Takada, Y.; Sand, D.; Heber, D. Pomegranate juice, total pomegranate ellagitannins, and punicalagin suppress inflammatory cell signaling in colon cancer cells. J. Agric. Food Chem. 2006, 54, 980-985. [CrossRef] [PubMed]

101. Baby, B.; Antony, P.; Vijayan, R. Antioxidant and anticancer properties of berries. Crit. Rev. Food Sci. Nutr. 2017, 13, 1-17. [CrossRef] [PubMed]

102. Bosetti, C.; Spertini, L.; Parpinel, M.; Gnagnarella, P.; Lagiou, P.; Negri, E.; Franceschi, S.; Montella, M.; Peterson, J.; Dwyer, J.; et al. Flavonoids and breast cancer risk in Italy. Cancer Epidemiol. Biomark. Prev. 2005, 14, 805-808. [CrossRef] [PubMed]

103. Peterson, J.; Lagiou, P.; Samoli, E.; Lagiou, A.; Katsouyanni, K.; La Vecchia, C.; Dwyer, J.; Trichopoulos, D. Flavonoid intake and breast cancer risk: A case-control study in Greece. Br. J. Cancer 2003, 89, 1255-1259. [CrossRef] [PubMed]

104. Serra, A.T.; Matias, A.A.; Frade, R.F.M.; Duarte, R.O.; Feliciano, R.P.; Bronze, M.R. Characterization of traditional and exotic apple varieties from Portugal. Part 2-Antioxidant and anti-proliferative activities. J. Funct. Foods 2010, 2, 46-53. [CrossRef]

105. Ha, S.K.; Park, H.Y.; Eom, H.; Kim, Y.; Choi, I. Narirutin fraction from citrus peels attenuates LPS-stimulated inflammatory response through inhibition of NF-kB and MAPKs activation. Food Chem. Toxicol. 2012, 50, 3498-3504. [CrossRef] [PubMed]

106. Cherniack, E.P. A berry thought-provoking idea: The potential role of plant polyphenols in the treatment of age-related cognitive disorders. Br. J. Nutr. 2012, 108, 794-800. [CrossRef] [PubMed]

107. Gasparrini, M.; Giampieri, F.; Forbes, T.; Battino, M. Strawberry extracts efficiently counteract inflammatory stress induced by the endotoxin lipopolysaccharide in Human Dermal Fibroblast. Food Chem. Toxicol. 2018, 114, 128-140. [CrossRef] [PubMed]

108. Chiva-Blanch, G.; Visioli, F. Polyphenols and health: Moving beyond antioxidants. J. Berry Res. 2012, 2, $63-67$.

109. Zhou, Y.; Zheng, J.; Li, Y.; Xu, D.P.; Li, S.; Chen, U.M.; Li, H.B. Natural polyphenols for prevention and treatment of cancer. Nutrients 2016, 8, 515. [CrossRef] [PubMed] 